\title{
The stopover behaviour of the Garden Warbler Sylvia borin in Obudu, southeast Nigeria
}

\author{
Trädgårdssångarens Sylvia borin beteende under rastning i Obudu, sydöstra \\ Nigeria
}

\author{
SOLADOYE B. IWAJOMO, ULF OTTOSSON, YAHKAT BARSHEP, ANDERS HELSETH, \\ MARK F. HULME, MATTHEW STEVENS \& JONAS WALDENSTRÖM
}

\begin{abstract}
The Garden Warbler breeds in the Palaearctic and migrates to sub-Saharan Africa for the non-breeding season. We studied its passage, body mass and moult at the Obudu Plateau in southeast Nigeria in October-December 2005 and December 2007-January 2008. In Nigeria, Garden Warblers in the Guinea savanna have been shown to increase body mass in October-November, preparing for migration to wintering sites further south. They begin to arrive at Obudu from mid-October and the numbers gradually increase with time; median date of passage was 3 December. This influx is clearly different from that which has been recorded for other sites in West Africa. The patterns in wing length and size-corrected body mass of individuals suggest a difference in the migration time of individuals of different sizes in the two years. Average fuel loads were lower at Obudu than has been reported in Central Nigeria. This, and the capture of moulting individuals, suggests that Garden Warblers may not embark

on a longer journey southwards in mid winter, and possibly may even winter at Obudu.

Soladoye B. Iwajomo, ${ }^{1,2^{*}}$ (correspondence to emailiwajom@yahoo.com), Ulf Ottosson, ${ }^{1,2}$ Yahkat Barshep, ${ }^{1,3}$ Anders Helseth, ${ }^{2}$ Mark F. Hulme, ${ }^{1,4}$ Matthew Stevens ${ }^{1,4}$ \& Jonas Waldenström ${ }^{2,5}$

${ }^{1}$ A. P. Leventis Ornithological Research Institute, P.O. Box 13404, Jos, Nigeria.

2 Ottenby Bird Observatory, PL 1500,

SE-38065 Degerhamn, Sweden.

${ }^{3}$ University of Cape Town, Rondebosch 7701, Cape Town, South Africa.

${ }^{4}$ University of St Andrews, Bute Building, Westburn Lane, St Andrews, KY16 9TS, UK.

${ }_{5}^{5}$ Section for Zoonotic Ecology and Epidemiology, Linnaeus University, SE-39185 Kalmar, Sweden.
\end{abstract}

Received 12 May 2010, Accepted 23 February 2011, Editor: D. Hasselquist

\section{Introduction}

Every year many Palaearctic bird species embark on migratory journeys from their northern breeding grounds to their wintering grounds in tropical Africa. In the course of this journey they cross vast ecological barriers such as the Sahara desert and the Mediterranean Sea (Moreau 1972). It has been suggested that a common strategy among Palaearctic migrants after crossing the Sahara into West Africa is to move with the Inter-Tropical Convergence Zone (Jones 1988). However, for some of these species, e.g. Lesser Whitethroat Sylvia curruca and the Subalpine Warbler S. cantillans, the Sahel zone serves as wintering ground, while others move further south after a short stay in this zone (Morel 1973, Jones 1985, Bensch et al. 1991).

Although the migration of Palaearctic bird species has been a topic of research for more than a hundred years, very few studies have focused on the intra-African part of the migratory journey. The aim of this study was to learn more about the nonbreeding movements of the Garden Warbler Sylvia borin within Nigeria, in sub-Saharan Africa. This is one of the most studied Palaearctic migrants, and has been used as a model species in many cage studies on fat accumulation and orientation (e.g. Gwinner \& Wiltschko 1980). The Garden Warbler breeds in Europe, North-West Kazakhstan and along the whole extension of the Russia/Kazakhstan border (Ryabitsev 2001, Wassink \& Oreel 2007) and winters over a wide range of Eastern and Western equatorial and Southern Africa, where they also make annual moult of all flight feathers. In West Africa they are widespread and common to abundant (Smith 1966, Gore 1981), frequenting outlying woods, fringing forest and bush (Serle \& Morel 1977) and generally habitats offering good tree cover (Elgood et al. 1994). During the nonbreeding season, they are usually solitary but can also be found in small groups gathering to feed at 
fruiting bushes and trees, as well as picking insects from leaves and twigs (Serle 1957).

The phenology of spring and autumn migration at two study locations in northern and central Nigeria has been reported by Ottosson et al. (2005), in which they illustrated the influx of migrant Garden Warblers in the Sahel in September, later spreading into the more lush Guinea savanna in the central part of Nigeria. Data from Amurum, outside Jos in Central Nigeria, show that the majority of birds fuel up and disappear from that area in November (Smith 1965, 1966, Ottosson et al. 2005). Elgood et al. (1966) considered the Garden Warbler to be a regular winter visitor to the southern forested areas of Nigeria. This is supported by records of individuals trapped in southwestern (Ludlow 1966) and southeastern Nigeria (Serle 1957) between November and April. Furthermore, there have been records of individuals ringed in the UK and Europe and recovered in Nigeria (Williamson 1964, Marchant \& da Prato 2002, Bakken et al. 2006). The recoveries of birds of the presumed same population indicate the Congo Basin to be the final destination for those Garden Warblers migrating to Nigeria (Sharland 1972, Fransson \& Hall-Karlsson 2008). It is however not known if the birds leaving the Guinea savanna embark on a single long flight to their final wintering ground or if they would still stopover at another location in Nigeria. Nonetheless, the importance of Nigeria to the migration ecology of this species can be seen from the hosting of migrating (Smith 1965, 1966, Ottosson et al. 2005) and overwintering individuals (Ludlow 1966). In this study, we targeted birds that were leaving the Guinea savanna of Nigeria presumably for the Congo Basin, by performing fieldwork in the Becheve Nature Reserve, at high altitude in the Obudu mountain range in southeastern Nigeria bordering Cameroon. Here we analyse the phenology of migration, pattern of body mass as well as moult of Garden Warblers. We use this data to give more details about the stopover behaviors and the phenology of migration of the species in Nigeria, and thus part of its intra-African migration.

\section{Methods}

\section{Study sites}

Data from bird ringing activities at Becheve Nature Reserve, Obudu $\left(6^{\circ} 25^{\prime} \mathrm{N}, 9^{\circ} 22^{\prime} \mathrm{E}\right.$, Figure 1), from 10 October-13 December 2005 and 12 December 2007-12 January 2008 was analyzed. Becheve Nature Reserve, c.70 hectares, is located on the Obudu plateau in southeastern Nigeria. The plateau, c. 1,500

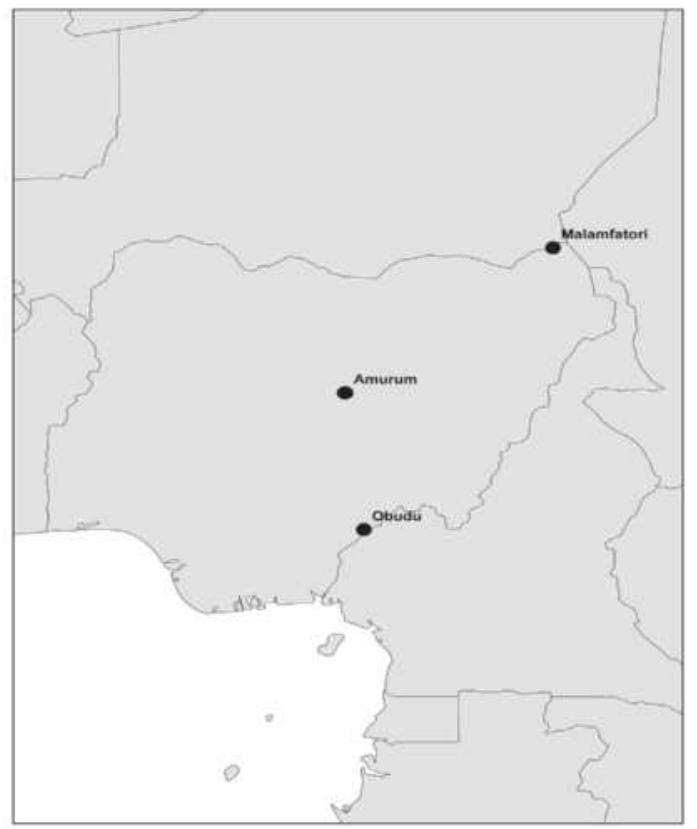

Figure 1. Map of Nigeria showing position of Obudu in relation to Malamfatori (Sahel savanna) and Amurum (Guinea savanna).

Karta över Nigeria med läget för Obudu i förhållande till Malamfatori (sahelsavann) och Amurum (guineasavann).

meters above sea level, consists mainly of grassland and relatively small montane forest patches and is a western extension of the Cameroon highlands (Borrow \& Demey 2001). The reserve contains $60 \%$ montane forest, $25 \%$ regenerating forest, $10 \%$ grassland and 5\% formerly cleared farmland. A total of 13 mist nets of lengths between 6-18 m were used in 2005 , with a total of 43,358 net meter hours, while in 2007/2008, 12 nets (between 6-12 m length) were used, with a total of 8,262 net meter hours. Mist netting was carried out at the same points during the two ringing seasons.

\section{Phenology of migration}

The number of captured Garden Warblers was plotted against trapping dates (Figure 2) to describe the timing of migration at Obudu. We also analysed the median passage date for individuals at this site.

\section{Morphometrics}

All birds trapped were ringed and aged using the EURING age codes as either first calendar year 
birds or adult birds. Standard measurements were taken, such as fat score from 0 representing no visible fat to a maximum of 9 (cf. Bairlein 1995), wing length to the nearest $1 \mathrm{~mm}$ using the maximum chord method (Svensson 1992) and body mass (to nearest $0.1 \mathrm{~g}$ ) using a Pesola spring balance. Moult of flight feathers was recorded according to Ginn \& Melville (1983); an old feather scored 0, growing feathers on a scale from 1-4 and a new feather scored 5 .

\section{Lean Body Mass and Fuel load}

Lean body mass (LBM) was estimated at $16.3 \mathrm{~g}$ for first year and $16 \mathrm{~g}$ for adults by averaging the ten lowest body masses recorded for each group. In adults the leanest individuals did not differ in wing length from the others (ANOVA F1, $28=0.316, \mathrm{p}=$ 0.578 ). However in first year individuals, the wing length of the leanest individuals was significantly shorter than other individuals (ANOVA F1, $116=$ $3.444, \mathrm{p}=0.066$ ). Hence, we have used $16 \mathrm{~g}$ as an estimated LBM of both age classes. The LBM was used to estimate fuel load in the captured birds (expressed as percent of the LBM) as $100 \times(B M-$ $\mathrm{LBM} / \mathrm{LBM}$, where BM is body mass as recorded.

We acknowledge that there is no sufficient overlap between the two periods of our trapping that allows for accurate investigation of seasonal

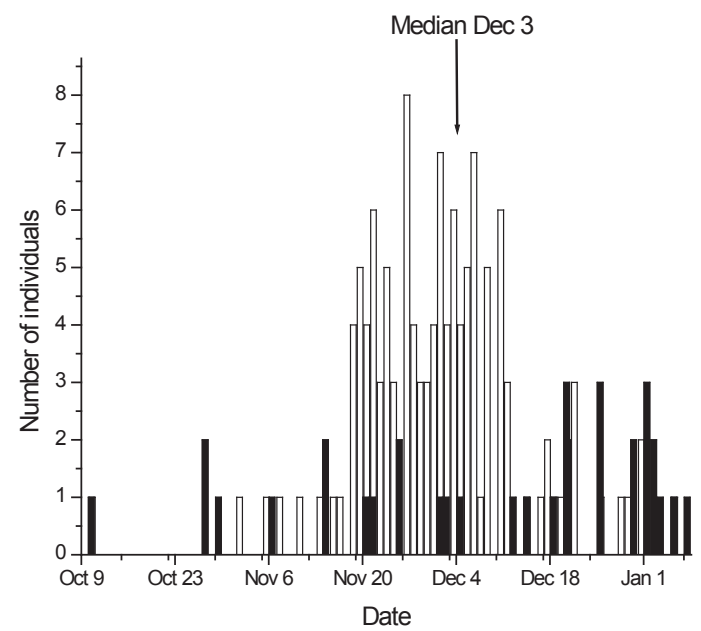

Figure 2. Number of captured Garden Warblers in relation to trapping date at Obudu. White bars represent first year birds and black bars represent adults.

Antalet fångade trädgårdssångare $i$ Obutu $i$ förhållande till fångstdatum. Vita staplar är första årets ungfåglar och svarta staplar äldre fåglar. trends in morphometrics. We therefore included the variable year in the tests for the relationships between standardized body mass, wing length and fuel load with date of capture. The interaction term year $\times$ date was also included in the linear model as a predictor variable. All analysis of standardized body mass, wing length and fuel load were based on 3-days moving averages, because our data was not sufficiently large to allow for analyses based on single day data.

Primary moult score was regressed against date, with date as dependent variable (Pimm 1976) thus estimating moult duration for the average bird. Although the linear regression method of analyzing moult data has been criticized as incorrect and the moult durations obtained overestimated (Underhill \& Zucchini 1988), we have used this method to obtain a comparative value. Reported values are means $\pm \mathrm{SD}$ and differences were considered significant at $\mathrm{p}<0.05$. All statistical analyses were carried out in SPSS version 11.0 (SPSS Inc. 2001).

\section{Results}

\section{General trapping results}

A total of 159 individuals were captured at Obudu during the 2005 and 2007-2008 ringing sessions out of which 7 individuals were recaptured in the 2005 ringing season and 1 individual in the 2007 2008 season. Of the total number of birds captured $118(74.2 \%)$ were first calendar year birds and 31 $(19.5 \%)$ were second calendar year or older birds. The age of $10(6.3 \%)$ individuals could not be determined.

\section{Phenology of migration}

Garden Warblers begin to arrive at Obudu from mid-October. Adult passage started a day earlier (11 October) than first year birds (12 October). A gradual increase in numbers was observed from late October, although the majority seemed to arrive from mid November to early December (median date: 3 December for both age classes, Figure 2). Garden Warblers were captured throughout December, but the capture rate dropped in late December and early January.

\section{Morphometrics}

Body mass was significantly related to wing length $\left(\right.$ ANOVA $\left._{1,145}=5.709, \mathrm{p}=0.018\right)$ but this relationship did not differ between first year and adult birds (Interaction of age and wing length; ANOVA $F_{1,144}$ 


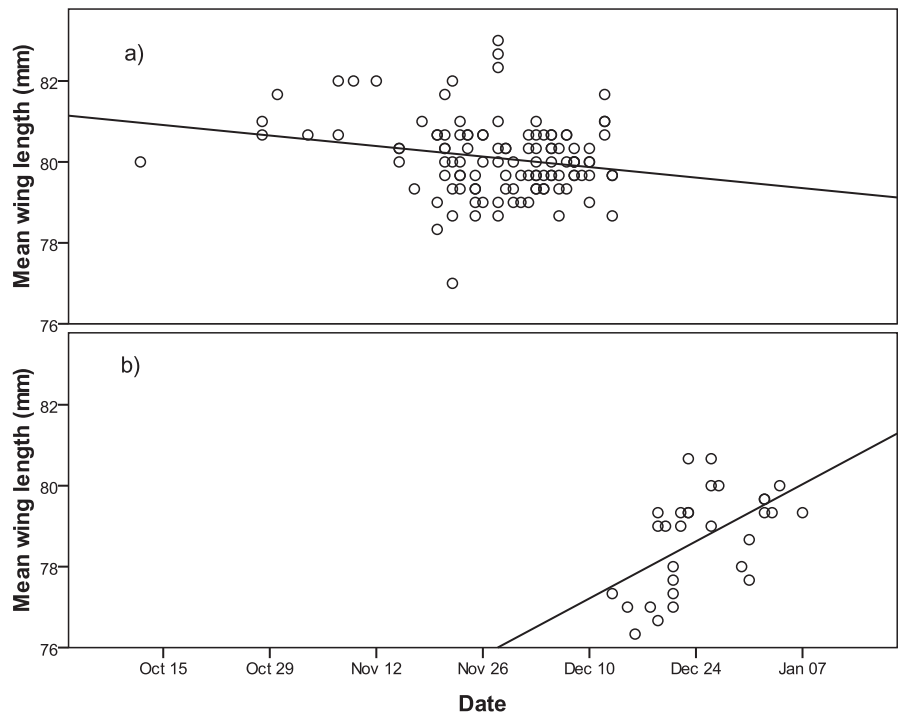

Figure 3. Trend in mean wing length $(\mathrm{mm})$ of Garden Warblers (based on 3 -day moving average) with date of capture in (a) 2005 and (b) 2007/2008 ringing seasons.

Trenden för vinglängdens medelvärde (mm) för trädgårdssångare (baserat på tre dagars löpande medelvärden) $i$ relation till fångstdatum för (a) 2005 och (b) 2007/2008.
$=0.613, \mathrm{p}=0.435)$. This made it possible to correct for wing length using the equation Standardized body mass $=7.859+$ wing length $\times 0.125$. Also, wing length did not differ significantly between the adult and first year birds (First year mean: $79.8 \pm$ $2.03 \mathrm{~mm}$, Adult mean: $79.8 \pm 2.04 \mathrm{~mm}$, ANOVA, $\left.\mathrm{F}_{1,146}=0.000, \mathrm{p}=0.993\right)$. We therefore pooled the standardized body mass and wing length data for the age classes together to analyse for trends within the season using 3-day moving averages of both variables. Standardized body mass (based on 3-day moving averages) was significantly related to date of capture (Linear model, $\mathrm{F}_{1,140}=8.632$, $\mathrm{p}=0.004$ ) but the slope of the relationship was significantly different between the two years in which birds were trapped (Linear model, interaction term year $\mathrm{x}$ date, $\left.\mathrm{F}_{1,140}=18.186, \mathrm{p}<0.0001\right)$. Analysing the years independently, there was a significant decline in standardized body mass with date (November to mid December) during the 2005 ringing season $\left(\mathrm{F}_{1,112}=5.369, \mathrm{p}=0.022, \mathrm{~B}=-0.002\right)$, whereas in the $2007 / 2008$ season it increased significantly with date from mid December to mid January $\left(\mathrm{F}_{1}\right.$, ${ }_{28}=11.595, \mathrm{p}=0.002, \mathrm{~B}=0.013$ ). Similarly, wing length (based on 3-day moving averages) was significantly related to date of capture (Linear model, $\left.\mathrm{F}_{1,140}=8.632, \mathrm{p}=0.004\right)$ but the slope of the relationship was significantly different between the two years in which birds were trapped (Linear model, interaction term year $\times$ date, $\mathrm{F}_{1,140}=18.186$, $\mathrm{p}<0.0001$, Figure 3). During the 2005 season there was a significant decline in wing length (based on 3 -day moving averages) with date in November to mid December $\left(\mathrm{F}_{1,112}=5.369, \mathrm{p}=0.022, \mathrm{~B}=-0.019\right)$, whereas in the $2007 / 2008$ season it increased significantly with date from mid December to mid January $\left(\mathrm{F}_{1,28}=11.595, \mathrm{p}=0.002, \mathrm{~B}=0.101\right)$.

\section{Fuel load}

Fuel load (Figure 4) did not differ between age classes (first year mean: $11.7 \pm 8.02 \%$ LBM, adult mean: $11.3 \pm 8.28 \%$ LBM, Linear model, $\mathrm{F}_{1,145}=$ $0.158, \mathrm{p}=0.691)$ and the pattern was the same for both seasons (Linear model, interaction term age $\mathrm{x}$ year, $\mathrm{F}_{1,145}=0.076, \mathrm{p}=0.783$ ). Based on 3-day moving average of data pooled for both ages, there was no trend in fuel load with date (Linear model, $\mathrm{F}_{1}$, ${ }_{143}=0.575, \mathrm{p}=0.449$ ) and this pattern was the same in the two years (Linear model, interaction term year $\mathrm{x}$ date, $\mathrm{F} 1,143=2.516, \mathrm{p}=0.115$ ). The maximum fuel loads were estimated at $44 \%$ and $35 \%$ of LBM in a first year and adult bird respectively.

\section{Moult}

A total of 13 actively moulting Garden Warblers (7.7\%, including recaptures) were recorded during the two ringing campaigns. Of this number, only one moulting individual $(0.78 \%)$ was trapped in October-mid-December 2005 while 12 individuals (30\%, including recaptures) were recorded in 
Figure 4. Trend in mean fuel load (\% LBM) of Garden Warblers (based on 3-day moving average) with date of capture in (a) 2005 and (b) 2007/2008 ringing seasons.

Trenden för fetthalt (\% LBM) hos trädgårdssångare (baserat på tre dagars löpande medelvärden) I förhållande till fångstdatum för (a) 2005 och (b) 2007/2008.

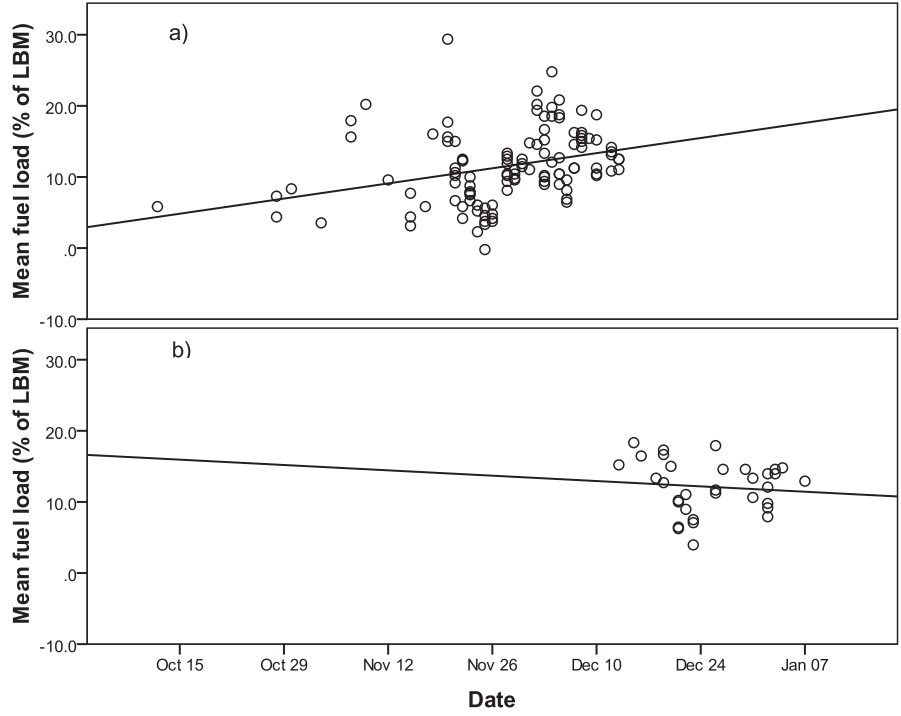

mid-December 2007 to mid-January 2008. The moulting individuals were all adults. One individual originally trapped on 15 December (moult score 2) was recaptured twice, on 31 December (moult score 17) and 6 January (moult score 18). Following the method of Pimm (1976) we estimate that the moult duration of the average bird may be about 90 days.

\section{Discussion}

The phenology of migration and body mass patterns of Garden Warblers at Malamfatori (Sahel zone of Northern Nigeria) and Amurum (Guinea savanna zone of Nigeria) has been reported by Ottosson et al. (2005). Also, data from previous studies have shown that the species does not spend the winter in the Sahel and Guinea Savanna (Ottosson et al. 2005, Smith 2007, Bayly \& Rumsey 2010). Thus, drawing from these published works, it is clear that during the autumn passage, and after a few months in the Guinea savanna region of Nigeria, Garden Warblers embark on a new leg of migration, presumably to their final wintering quarters. After two field seasons at Becheve Nature Reserve on the Obudu plateau, we can now provide additional data on the Garden Warbler's intraAfrica migration and the behaviour of this species in Nigeria. The passage of Garden Warblers at Obudu commenced from mid-October and peaked by 3 December, after which a gradual decline was observed. Although no Garden Warblers were captured after $8^{\text {th }}$ January 2008, two individuals were observed in the field within the last four days of trapping. Furthermore, Garden Warblers were first captured relatively earlier at our study site (11 October) compared to dates reported by previous studies in forested areas of Nigeria (18 November at Imesi-ile $\left(7^{\circ} 33^{\prime} \mathrm{N} 4^{\circ} 33^{\prime} \mathrm{E}\right.$; Ludlow 1966) and 15 October at Ibadan $\left(7^{\circ} 23^{\prime} 47^{\prime \prime N} 3^{\circ} 55^{\prime} 0^{\prime \prime E}\right.$; Parker 1968). This difference in arrival dates support the suggestion of Smith (1963) that after crossing the Sahara, Garden Warblers move southwards slowly while feeding on the way. The median passage date at Obudu is about 30 days after the reported date for birds passing through the Guinea savanna region of Nigeria (Ottosson et al. 2005). This clearly shows a distinct intra-African movement of this species within Nigeria, the timing of which differs from the autumn influx from their European breeding grounds that occurs in September-November. Also, the peak passage reported by Parker (1968) for birds trapped in Ibadan, Southwest Nigeria was 26 days earlier than we have reported at our study site.

Three-day moving averages of standardized body mass and wing length of Garden Warblers at Obudu showed a negative trend with date in the 2005 season but increased in the 2007/2008 season, suggesting that larger birds pass through the study site earlier than smaller ones but later in the season there is another influx of large individuals. 
There was no significant change in the fuel load of individuals trapped over the season. Also, the average fuel load recorded at Obudu (11.6\% of LBM, adults and juveniles pooled together) is lower than the $21.3 \%$ recorded for passing Amurum in autumn (Ottosson et al. 2005). This suggests that from Obudu, many Garden Warblers may not embark on a longer journey further south. First year and adult individuals with maximum fuel loads may however be capable of covering a distance of about 2,500 km and 2,100 km respectively in still air and at an altitude of $1000 \mathrm{~m}$, according to the Pennycuick flight model (Pennycuick 1989), assuming a wing span of $0.239 \mathrm{~m}$, wing area of $0.011 \mathrm{~m}^{2}$ and an aspect ratio of 5.24 (Pennycuick 1989).

Furthermore, it has been suggested that the timing of moult in birds should not overlap with migration, considering the energetic cost of the two processes (Jenni \& Winkler 1994, Berthold 1996) and implying that the efficiency of migration may be constrained by the process of moulting, especially where the birds have to cover great distances. Some studies have shown that many palaearctic migrants in the tropics including the Garden Warbler moult their flight feathers at their wintering grounds (Ludlow 1966, Ginn \& Melville 1983, Svensson 1984).

Data from previous studies have shown that winter moult in Garden Warblers occurs between December and April (Williamson 1964, Pearson 1973). We confirm this with record of all moulting individuals captured between December and January. However it seems that primary feather moult of birds trapped in Obudu may have started in November considering the moulting individual trapped on 3 December 2005, having five primaries in active moult. Our record of moulting individuals suggests that some birds winter at our study site. One moulting individual was trapped three times over a period of 22 days further supporting the suggestion that either these birds were stopping-over for an extended period, possibly for the purpose of moulting, or that they had reached their final wintering ground. Pearson (1973) estimated the moult duration of Garden Warblers wintering in Uganda to be about 70 days. In this study we estimated the moult period to be about 90 days. As a result of the paucity of our moult data which consequently limited the method of analysis, we cannot conclude that moult duration we have obtained is a true reflection of the behaviour of this species at Obudu.

The early capture of moulting individuals as compared to that of Ludlow (1966) also suggests that birds captured at Obudu may differ in terms of origin as compared to the earlier records in Southwest Nigeria. According to Williamson (1964), the moult of secondaries usually commence when the renewal of primaries is well advanced. However, in our study we recorded two individuals which had not dropped any primary feather but had commenced the renewal of a secondary or tertial feather. Perhaps the sequence of moult in Garden Warblers is more variable than has been reported in earlier studies. It can be noted that moult patterns can be very variable in other Sylvia warblers (e.g., Hasselquist et al. 1988, Lindström et al. 1993).

Although wintering sites are often associated with the commencement of moult in the remiges, particularly in species which undergo a complete winter moult, such sites may not be the final wintering grounds. The resulting strategy of moult-migration has been reported in Great Reed Warblers moulting in Ghana (Hedenström et al. 1993) and Willow Warblers in Ivory Coast (Salewski 1999 and 2002). Similarly, an overlap of moult with migration has been documented in several studies (Pearson \& Backhurst 1976, Herremans 1990, Schaub \& Jenni 2000). Perhaps the reduction in capture rate experienced towards the end of our survey period could be attributed to Garden Warblers at our study site exhibiting moult-migration or that the birds had learnt to avoid the nets?

In this study we conclude that after departing the Guinea savanna region of Nigeria, many Garden Warblers embark on another journey, possibly to the southeastern part of Nigeria where they stopover. During this period many individuals commence the moult of flight feathers, a situation which suggests they may winter at this site. Following our assumption that birds migrating to Nigeria are en-route to winter grounds beyond the Congo Basin, it is possible that some individuals continue their journey southwards with partially moulted flight feathers. However, the pattern in fuel load does not suggest an intention for longer migration. The fact that surveys previously conducted in Southwestern Nigeria did not record any moulting individual within the time of year that our study was conducted also suggests that the population we have studied is of a different origin.

\section{Acknowledgements}

This project has been financially supported by the Swedish Ornithological Society through Lindberg's Memorial Foundation and through Ottenby Bird Observatory. We would like to thank Dennis Hasselquist, an anonymous referee, Christian Hjort 
and Peter Jones for their valuable comments on earlier versions of the manuscript. This is contribution no. 243 from Ottenby Bird Observatory and no. 44 from A. P. Leventis Ornithological Research Institute.

\section{References}

Bairlein, F. 1995. European-African Songbird Migration Network: Manual of Field Methods. Institute für Vogelforschung, Wihelmshaven.

Bakken, V., Runde, O. \& Tjörve, E. 2006. Norsk ringmerkingsatlas. Vol 2. Stavanger Museum, Stavanger.

Bayly, N. J. \& Rumsey, S, J. R. 2010. Garden Warbler Sylvia borin migration in sub-Saharan West Africa. Ringing \& Migration 25: 59-61.

Bensch, S., Hasselquist, D., Hedenström, A. \& Ottosson, U. 1991. Rapid moult among palaearctic passerines in West Africa - an adaptation to the oncoming dry season? Ibis 133: 47-52.

Berthold, P. 1996. Control of bird migration. Chapman and Hall, London, UK.

Borrow, N. \& Demey, R. 2001. Birds of Western Africa. Christopher Helm, London.

Elgood, J. H., Heigham, J. B., Moore, A. M., Nason, A. M., Sharland, R. E. \& Skinner, N. J. 1994. The Birds of Nigeria. B.O.U. Check-list No.4 (Second Edition). British Ornithologists' Union, UK.

Elgood, J. H., Sharland, R. E. \& Ward, P. 1966. Palaearctic migrants in Nigeria. Ibis 108: 84-116.

Fransson, T. \& Hall-Karlsson, S. 2008. Svensk ringmärkningsatlas. Vol. 3. Stockholm.

Ginn, H. B. \& Melville, D. S. 1983. Moult in Birds. BTO Guide 19. British Trust for Ornithology, Tring.

Gore, M. E .J. 1981. Birds of the Gambia. British Ornithologists' Union, London.

Gwinner, E. \& Wiltschko, W. 1980. Circannual changes in migratory orientation of the Garden Warbler, Sylvia borin. Behav. Ecol. Sociobiol. 7: 73-78.

Hasselquist, D., Hedenström, A., Lindström, Å., \& Bensch, S. 1988. The seasonally divided flight feather moult of the Barred Warbler Sylvia nisoria - A new moult pattern in European passerines. Ornis Scandinavica 19: 280-286.

Hedenström, A., Bensch, S., Hasselquist, D., Lockwood, M., \& Ottosson, U. 1993. Migration, stopover and moult of the Great Reed Warbler Acrocephalus arundinaceus in Ghana, West Africa. Ibis 135: 177-180.

Herremans, M. 1990. Body-moult and migration overlap in Reed Warblers (Acrocephalus scirpaceus) trapped during nocturnal migration. Gerfaut 80: 149-158.

Jenni, L. \& Winkler, R. 1994. Moult and ageing of European passerines. Academic Press, London.

Jones, P. 1985. The migration strategies of palaearctic passerines in West Africa. Pp 9-21 in Migratory Birds: problems and prospects in Africa (MacDonald, A. \& Goriup, P., eds.) 14th ICBP conference 1983. International Council for Bird Preservation, Cambridge. pp. 9-21.

Jones, P. J. 1988. Community dynamics of arboreal insectivorous birds in African savannas. In: Newberry D.M., Prins H.H.T. \& Brown N.D. (eds) Dynamics of Tropical Communities. Blackwell, London. pp. 421-447.
Lindström, Å., Pearson, D. J., Hasselquist, D., Hedenström, A., Bensch, S. \& Åkesson, S. 1993. The moult of Barred Warblers Sylvia nisoria in Kenya - evidence for a split wing-moult pattern initiated during the birds' first winter. Ibis 135: 177-180.

Ludlow, A. R. 1966. Body-weight changes and moult of some Palaearctic migrants in Southern Nigeria. Ibis 108: 129-132.

Marchant, J. H. \& da Prato, S. 2002. Garden Warbler Sylvia borin. Pp. 559-561 in The Migration Atlas: movements of the birds of Britain and Ireland (Wernham, C. V., Toms, M. P., Marchant, J. H., Clark, J. A., Siriwardena, G. M. \& Baille, S. R., eds.) London: T. \& A. D. Poyser.

Moreau, R. E. 1972. The Palaearctic-African Bird Migration System. London: Academic Press.

Morel, G. 1973. The Sahel zone as an environment for palaearctic migrants. Ibis 115: 413-417.

Ottosson, U., Waldenström, J., Hjort, C. \& McGregor, R. 2005. Garden Warbler Sylvia borin migration in subSaharan West Africa: phenology and body mass changes. Ibis 147: 750-757.

Pearson, D. J. 1973. Moult of some palaearctic warblers wintering in Uganda. Bird Study 20: 24-36.

Pearson, D. J. \& Backhurst, G. C. 1976. The southward migration of palaearctic birds over Ngulia, Kenya. Ibis 118: 78-105.

Pennycuick, C.J. 1989. Bird flight performance: a practical calculation manual. Oxford University Press, Oxford.

Pimm, S. L. 1976. Estimation of the duration of bird moult. Condor 78: 550.

Rappl, R., Wiltschko, R., Weindle, P., Berthold, P. \& Wiltschko, W. 2000. Orientation behavior of Garden Warblers (Sylvia borin) under monochromatic light of various wavelengths. Auk 117: 256-260.

Ryabitsev, V. K. 2001. Birds of the Urals, Cisural Region and West Siberia. Urals University Press, Yekaterinburg.

Salewski, V. 1999. Untersuchungen zur Überwinterungsökologie paläarktischer Singvögel in Westafrika unter besonderer Berücksichtigung der Wechselwirkungen zu residenten Arten. Berlin: W. \& T. Verlag.

Salewski, V. 2002. Different wintering strategies of two Palaearctic migrants in West Africa - a consequence of foraging strategies? Ibis 144: 85-93.

Schaub, M. \& Jenni, L. 2000. Body mass of six long-distance migrant passerine species along the autumn migration route. J. Ornithol. 141: 441-460.

Serle, W. 1957. A contribution to the Ornithology of the Eastern region of Nigeria. Ibis 99: 371-418, 628-685.

Serle, W. \& Morel, G. J. 1977. A Field guide to the birds of West Africa. London.

Sharland, R. E. 1972. Ringing in Nigeria in 1971: 14th Annual Report. Nigerian Ornithol. Soc. Bull. 9: 13-16.

Smith, V. W. 1963. Arrival dates of the Garden Warbler Sylvia borin in Central Nigeria. Ibis 105: 561-563.

Smith, V. W. 1965. Palaearctic migrants at Vom, Plateau Province, over five seasons. Nigerian Ornithol. Soc. Bull. 6: 26-44.

Smith, V. W. 1966. Autumn and spring weights of some Palaearctic migrants in Central Nigeria Ibis 108: 492-512.

Smith, V. W. 2007. Garden Warbler Sylvia borin migration in sub-Saharan West Africa: a comment on Ottosson et al. (2005). Ibis 149: 412-413.

SPSS Inc. 2001. SPSS for Windows. (Version 11.0). SPSS 
Inc., Chicago, IL.

Svensson, L. 1984. Identification Guide to European Passerines, 3rd edn. L. Svensson, Stockholm.

Svensson, L. 1992. Identification Guide to European Passerines, 4th edn. L. Svensson, Stockholm.

Underhill, L. G. \& Zucchinni, W. 1988. A model for avian primary moult. Ibis 130: 358-372.

Urban, E. K., Fry, C. H. \& Keith, S. eds. 1997. The Birds of Africa. Vol. 5. Academic Press Limited, London.

Wassink, A. \& Oreel, G. J. 2007. The Birds of Kazakhstan. De Cocksdorp, Texel.

Williamson, K. 1964. Identification guide for ringers. The genus Sylvia. Identification guide No. 3. Holywell Press, Oxford.

\section{Sammanfattning}

Trädgårdssångaren häckar i Europa och övervintrar i Afrika, framförallt kring ekvatorn. I Västafrika är den en spridd och vanlig vintergäst där trädinslaget är rikligt. Vi har tidigare beskrivit flyttningens förlopp i Nigeria från två orter i norra respektive centrala Nigeria. I Sahelområdet anländer de första trädgårdssångarna $\mathrm{i}$ september för att senare sprida sig söderut till den mer beskogade Guineasavannen. I centrala Nigeria lägger de på sig nya fettreserver och startar en ny flyttning i november. De slutgiltiga övervintringskvarteren återfinns $\mathrm{i}$ Kongobäckenet. Vi studerar här denna sista flyttningsetapp genom att fånga fåglar på Obudu-platån i sydöstra delen av Nigeria.

Vi fångade trädgårdssångare vid Becheve Nature Reserve, Obudu-platån $\left(6^{\circ} 25^{\prime} \mathrm{N}, 9^{\circ} 22^{\prime} \mathrm{E}, 1500 \mathrm{~m}\right.$ över havet; Figur 1) 10 oktober-13 december 2005 och 12 december 2007-12 januari 2008. Vi använde 13 slöjnät, 6 till 18 meter långa och sammanlagt 43.358 nätmetertimmar. Nätplatserna var desamma båda studieåren. Alla fångade fåglar ringmärktes, åldersbestämdes och fettklassades. Ruggningsstadiet beskrevs med en etablerad skala för flygfjädrar, från 0 för en oruggad fjäder till 5 för en helt utvuxen, ny fjäder.

Det fanns ingen skillnad i vinglängd beroende på vikt hos varken gamla eller unga fåglar. Som en konsekvens av detta valde vi att använda 16,0 gram (medelvärdet av de 10 fåglarna med lägst vikt) som den fettfria vikten för alla fåglarna. Fettfri vikt användes för att beräkna mängden lagrat flygbränsle och som procentuell del av fettfria vikten. De två tidsperioderna överlappande endast delvis, och för att korrigera för detta togs år och interaktionen $\stackrel{a}{r} \times$ datum med som faktorer i analyserna. Vi använde rullande tre-dagars medelvärden för att undvika datapunkter baserade på enskilda individer. Genom regressionsanalys studerades hur ruggningspoängen varierade med datum för att be- stämma ruggningens längd för olika individer.

Totalt fångades 159 trädgårdssångare, varav 94\% åldersbestämdes (118 ungfåglar och 31 adulta; Figur 2). Kroppsvikten var signifikant korrelerad med vinglängd och varierade likartat mellan åldersklasserna. Därför kunde vi korrigera för vinglängd i analyserna. Vinglängden skiljde sig inte heller mellan åldersklasserna och vi slog därför samman data när vi analyserade trender inom säsongen. Den standardiserade kroppsvikten var signifikant korrelerad med fångstdatum, men linjens lutning skiljde sig mellan de två åren. För fåglar fångade 2005 minskade kroppsvikten med fångstdatum, medan förhållandet var det omvända för säsongen 2007/2008. Liknande mönster sågs för vinglängd (Figur 3): 2005 minskade vinglängd med datum, medan den ökade över tid under säsongen 2007/2008. Fuel load varierade inte mellan åldersklasserna och uppvisade inga signifikanta trender över tid (Figur 4). Maximal fuel load beräknades till $44 \%$ respektive $35 \%$ av den fettfria vikten för ungfåglar och adulta fåglar.

Tretton av de fångade fåglarna (alla adulta) var under aktiv ruggning, varav endast en fångades mellan oktober och mitten av december (2005) jämfört med 12 individer från mitten av december 2007 till mitten av januari 2008. Ruggningens förlopp bestämdes till ca 90 dagar .

Studien förstärker bilden av ett uppdelat sträck av trädgårdssångare i Nigeria. Höststräcket kan delas in i en tidig del där fåglarna rör sig från Sahel till Guineasavannen, varifrån de efter en tid påbörjar en ny flyttningsrörelse till de slutgiltiga övervintringskvarteren. Sträcktoppen vid Obudu låg ca 30 dagar efter sträcktoppen i Guineasavannen.

Vinglängden visade viss variation inom och mellan säsongerna, vilket möjligen antyder att olika populationer passerar Obudu. Fettmängden i relation till den fettfria vikten varierade inte med datum. I genomsnitt var den $11,6 \%$, vilket är lägre än i centrala Nigeria $(21,3 \%)$. Detta antyder att den kvarvarande flyttningsetappen från Obudu är relativt kort, men fettet räcker ändå till 210-250 mils flyttning, antagande avsaknad av vind, en altitud om 1000 meter, ett vingspann om 0,239 meter, vingarea om $0,011 \mathrm{~m}^{2}$ och en kvot om 5,24 i Pennycuicks flygekvation.

Ruggning sammanfaller normalt med flyttning eftersom båda kräver mycket energi. Att vi fann ruggande fåglar kan antyda att en del individer övervintrade $\mathrm{i}$ vårt undersökningsområde. En av de ruggande fåglarna återfångades också efter 22 dagar. 